\title{
THE DEVELOPMENT OF SANITARY AVIATION IN PRE-WAR POLAND - HISTORICAL ASPECTS
}

\author{
Robert REZNER, MA
}

robertrezner@wp.pl

\begin{abstract}
This article looks at some historical aspects of sanitary aviation in Poland in the context of global aviation and its influence on the development of Polish aviation. The research was limited to the period from the rise of sanitary aviation until the outbreak of the Second World War. The first part of the article examines the development of sanitary aviation in the world. It includes mainly technical aspects starting from free balloons, flying ambulances and the first sanitary airplanes. The article also examines the legal aspects pertaining to the International Conference of the Red Cross in 1925. The main part of the article is concerned with the development of sanitary aviation in Poland. The history is divided into two parts, 1924-1927 and 1927-1939. The division was based on the legal act regulating the principles of operation of sanitary aviation, which changed its further development.
\end{abstract}

Keywords: aviation, medical rescue, sanitary aviation, history

\section{Introduction}

The basic operations of medical rescue teams consist in instant help in the event of accidents. In Poland, rescue operations with air transport are carried out by the Independent Public Establishment of Healthcare Aviation Emergency Unit (SP ZOZ LPR) which ensures help for each person in a situation that involves sudden health risk. Nowadays, its mission is to bring medical help to people in need in the shortest possible time. SP ZOZ LPR brings medical help - medical

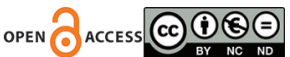


emergency procedures (flights to accidents, sudden illnesses and helping their victims) sanitary air transport (transport of patients requiring medical help between healthcare units), medical air transport from out of Poland (e.g. transport of Polish citizens, victims of accidents or sudden illness occurring beyond Polish borders) and medical air transport from Poland to abroad. Today, the operation of SP ZOZ LPR is carried out at 22 bases, by two EMS transport teams (Emergency Medical Service).

The operations of teams are carried out with the use of EC135 P2+ helicopters. The obsolete and run-down $\mathrm{Mi}-2+$ machines were replaced with modern Eurocopters, which allowed the effective range of operation to be increased by up to $80 \mathrm{~km}$ achieved in 22 minutes. EC135 P2+ is equipped with the most advanced cockpit systems that allow for safe performance of rescue flights in severe weather conditions during the day and night.

The purpose of the article is to explain sanitary aviation in Poland in its development on a global scale. The research problem was posed in the following way: How was sanitary aviation developing in Poland in the interwar period and what was the influence that global sanitary aviation exerted on it?

In the article the researched period was narrowed down from the rise of sanitary aviation to the outbreak of the Second World War 1924-1939. In order to solve the researched problem, the theoretical research methods of analysis, synthesis, abstraction and generalisation were used.

\section{The beginnings of Red Cross Aviation in the world}

On 21st November 1783, Jean-Francois de Rozier and Marquis d’ Arlandes were the first in the world to make a free balloon flight covering a distance of $9 \mathrm{~km}$ at a height of $100 \mathrm{~m}$. It was Jean-Francois de Rozier, the pioneer of aviation and also inventor of the respirator, gas mask and diving suit, who for the first time noticed the possibility of transporting ill people by air.

The idea of the first ambulance was introduced by the French army doctor Dominique Jean-Francois Larrey, participant in the French Revolution and later, 
Napoleonic battles. In 1792, he was inspired by horse artillery, so called flying artillery, and came up with the idea to build a lightweight vehicle of one or two axes with one or two harnessed horses which he called a flying ambulance. The vehicle passed its test during the fight as the first field ambulance (Image 1).

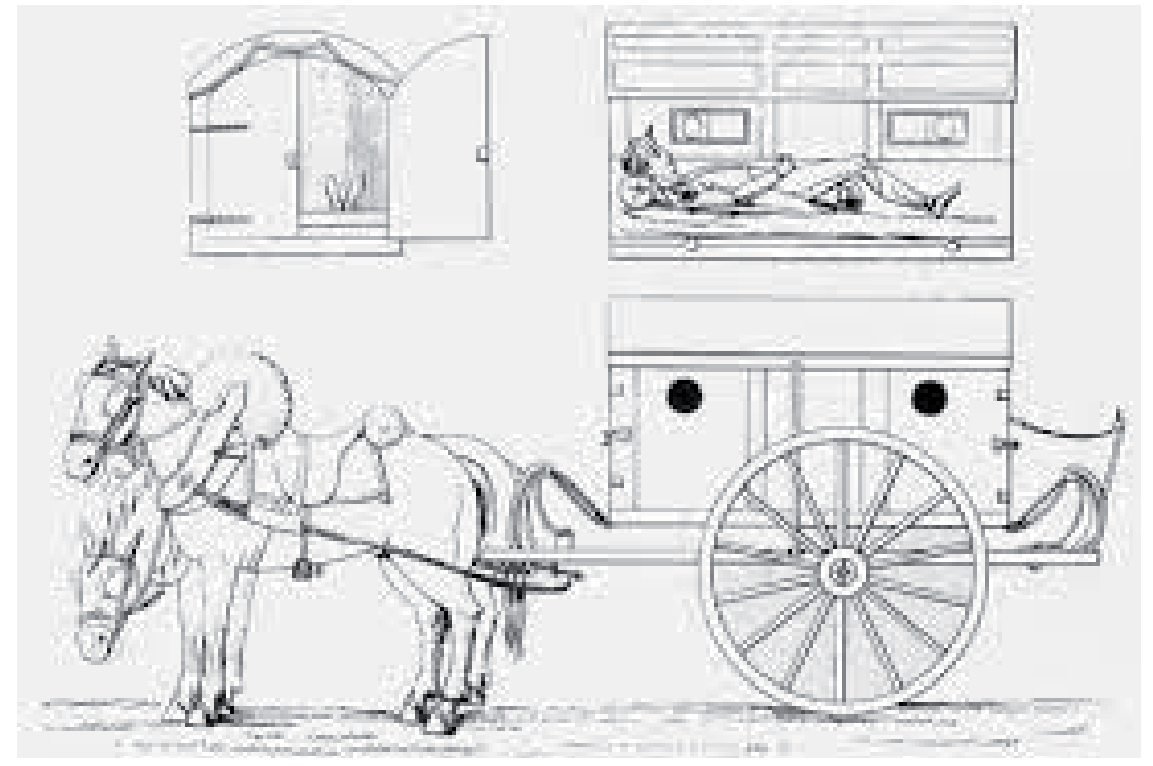

Image 1. Flying Ambulance (www.flickr.com)

Although Dominique Jean- Larrey used the term "flying ambulance" for the first time, the use of the air to save human life was strictly speaking described for the first time in history by Julius Verne in his book "Robur the Conqueror" where the crew of the Albatross balloon saves shipwrecked people at sea.

The first documented use of balloons for evacuation of the injured dates to 1870 when during the siege of Paris, it was possible to evacuate around 160 soldiers by air (Armstrong 1952).

In 1890, Dr.. M. de Mooy, the head doctor of the Dutch army, suggested building the injured evacuation system by means of rescue aircraft conducting searches, equipped with searchlights of high power. The project planned to equip each aircraft in a small hospital. Doctor de Mooy`s concept was never realised because the Dutch government thought it was too risky. 
The first attempt to use airplanes as a means of transport for the injured was made by two officers of the American army in 1909. Capitan G. Gosman and Lieutenant A. Rhoades built a plane from their own funds. An unfortunate accident during the test flight in Fort Barrancas, Florida delayed the development of rescue aviation until World War I (Sarnecky 1999).

In 1912, the French senator, Emile Reymond, was the first in history to take part in a specially designed exercise in search and rescue on the Berriot 9 plane. In September the same year, during the maneuvers, Poitou flew over the exercise area where he picked up injured people and transported them to medical points. After this successful experiment, the French doctor, M. Gautier, commented in August 1913 "we are able to revolutionise military surgery if we adopt planes for transport of the injured" (Haller Jr 2011).

Similar reflections were made in 1913 in Societe de Medicin Militaire when M. Uzac and Charles Julliot introduced alterations to the Geneva Convention, recognising the legal status of rescue aviation (Haller Jr 1992).

Flying ambulances during warfare were to be protected. However, the annex was looked into only 10 years later when at the International Red Cross conference, a regulation was introduced into the Geneva Convention about the status of sanitary aviation. The regulation obliged potential adversaries to use the aircraft only and exclusively for the transport of the injured and also obliged the sides to publish the details about these ships. Events of non compliance with the above regulations were the reason why there were attempts to adjust the legal norms to reality and only two years later, the final regulation was adopted at the assembly of the Red Cross Society 10.10.1925 (Gałązkowski and Kłosiński 2005).

In November 1915, when the Serb army withdrew from the Albanian mountains, territory capitan Dangelzer and Lieutenant Paulhan successfully evacuated injured soldiers from Mirtovica to Prizren and further to Villon by air (Haller Jr 2011).

During the First World War, the greatest input into the development of sanitary aviation was made by Doctor Eugene Chassaing. It was he who followed the example of Doctor Raymond and started to use aviation transport in practice for the evacuation of injured soldiers from the area of war operations. Chassaing, who cooperated with Justin Goddart, used room in the fuselage of the military aircraft Dorant AR II for the stretchers, which allowed soldiers to be evacuated 
from the Soissons sector. Soon after, Chassaing had six planes of this type and, in April 1918, two of these planes assisted in the evacuation of soldiers from Flanders (Image 2).

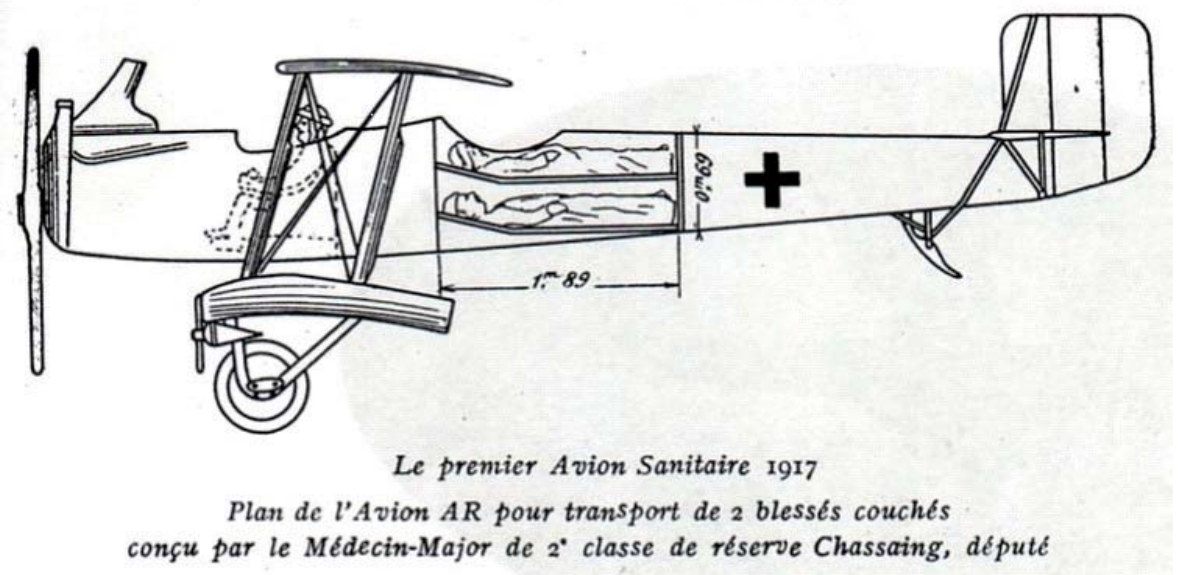

Image 2. Chassaing's design (www. fr.wikipedia.org/wiki/Dorand_AR.1)

Chassaing, by proving the practical application of aviation rescue medicine during evacuation, provided an example to be followed by other aviators who started to collect injured friends while returning from military operations. After the war, he was assigned to Morocco, where the French side equipped him with 60 type Breguet 14-2-A airplanes to be converted for rescue needs. And so until 1921, all 60 models were used reguarly in rescue operations. Breguet XIV -T planes with the removal of the turret for the gun and remodelling of side doors in the cockpit for double stretchers were easily used in rescue operations. Chassaing, who was recognised as the father of aviation rescue teams, wanted his ideas to spread across the whole world until the end of the 1920s. The French continued the expansion of aviation medical rescue during short missions in Morocco and Syria between 1921-1925. Then, the French established the Medical Aviation Service under the command of Colonel Cheutin. Also the French presented "aerochir". However, "<<aerochir >> was not successful because transporting the injured to hospital appeared more effective than transporting the medical staff to them, leaving behind all medical equipment in hospital. For this reason, transport of the injured, the French used for the first time a large type of plane, Breguet-Limousine, 
which was able to transport from eight to ten strechers at the same time and a smaller biplane Hanriot which carried two strechers put into the plane through the side hatch in the cockpit. Pilots liked Hanriot the most for two reasons: first because of its ability to land and start at short distances and secondly because of its durability. It worked well during the evacuation of the injured to carry them to the field dressing station twenty miles away to the line where a Breguet plane took over and transported them further to hospitals. Until 1920, the Moroccan Air Emergency Service consisted of 17 airplanes of type Hanriot and 26 planes of type Breguet (Haller Jr 2011).

France, which was an example of development and implementation of sanitary aviation, infected the whole world with this idea: among others, the United States, Great Britain, Germany, Italy, and Poland. The British even contemplated establishing an air convoy on the model of motorised rescue convoys. In spite of those efforts and visions, Britain did not have organised medical transport until 1931. Instead, they focused on gathering an aviation staff of volunteers organised under the auspices of the British Red Cross and sanctioned by the Ministry of Aviation. In 1923, at the International Conference of the Red Cross, the delegates debated the effectiveness of medical aviation during the war and what form of protection of medical rescue should be applied by the forces of the enemy. The result of this debate became the foundation and basis for the committee which presented the results at the International Conference of the Red Cross in 1925. The committee prepared an appendix to the Geneva Convention of 1906 reasserting the protection of medical planes serving with their equipment exclusively for the transport of the ill and injured or for the transport of their own medical staff and medical equipment. The appendix also introduced prohibition for medical aircraft to transport signalling equipment, weapons or photographic equipment. Moreover, the appendix prohibited (unless the enemy side agreed) the medical emergency aviation from flying directly over the firing line or even getting close to it. To secure protection of aviation emergency rescue, the appendix included a recommendation to register aircraft designated for medical rescue. The machines themselves were not arrested, but they had to be made available for inspection. Finally, the appendix ordered all countries to use the colours of aviation emergency: a red cross on white background on the wings and under them and also on both sides of the plane fuselage (Haller Jr 2011). 


\section{Sanitary aviation in pre-war Poland}

2.1 In Poland since 1924, the inspector of healthcare services, General Felicjan Sławoj-Składkowski, initiated creation of Polish Sanitary Aviation and, as a result, the Committee for Creation of Sanitary Aviation in Poland was established. Simultaneously, the Executive Committee of Sanitary Aviation was formed under retired Brigadier Doctor Witold Horodyński. His closest cooperators were Colonel (Pharmacist) Stefan Krupiński, Col. Doctor Władysław Gorczycki and Lieutenant Colonel Doctor Feliks Różycki. Simultaneously, Brigadier Doctor Pilecki - Sanitary Head of District of VII Corps Poznań with the help of Col Doctor Jarociński commander of 6th Sanitary Batallion (through the work of mechanics of course) adapted the plane Albatros C-X to fulfill sanitary tasks. The plane was owned by 3 aviation regiments stationed in Poznan and the first trials of sanitary flights were initiated on the nearby training grounds (Przybylski 2003) One year later, that is in April 1925, two planes were designated for the service: Hanriot HD $14 S$ and Breguet XIV Tbis purchased with the money collected by the military sanitary unit and Polish Pharmaceutical Society. The third Hanriot HD $14 S$ was ordered in September 1925. The mechines ' potential is worth mentioning. In comparison with Hanriot HD 14S which could take one ill person, Breguet XIV Tbis seemed promising because it could take on board a doctor and two ill people apart from the pilot (Image 3).

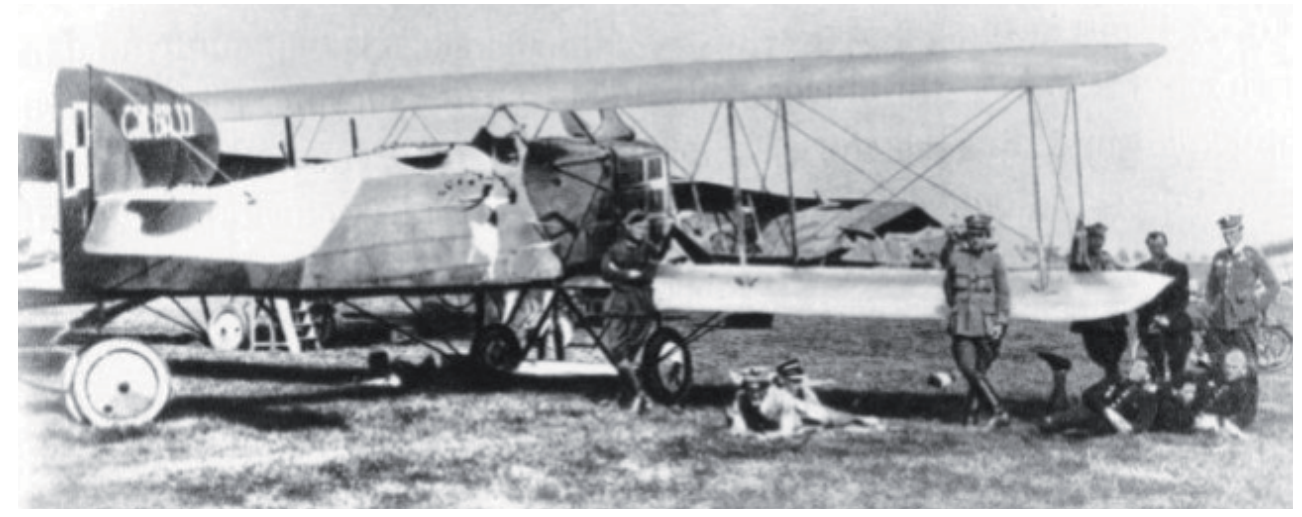

Image 3. Airplane Breguet XVI (www.samolotypolskie.pl) 
The involvement of society had a positive impact on the formation of rescue aviation in Poland. Private investors, doctors, and pharmacists transferred large donations or voluntarily taxed themselves for this noble cause. The first aircraft were assembled from parts which were separately delivered to Central Aviation Plant in Warsaw. After technical test flights, they were passed to particular units. The first test flight took place on 14th September 1925. The airplane Hanriot was given to 1 Aviation Regiment. A month later, that is on 6.10.1925, a technical acceptance flight was made. Capitan pilot Ignacy Giedgowd carried out a control rescue flight transporting an injured patient who was General Sławoj-Składkowski himself. The second Hanriot was given over to 11 Aviation Regiment in Lida. The first actual sanitary flight took place on 24.10.1925 where a seriously injured soldier was transported from Dęblin regional hospital to I District Hospital in Warsaw.

A great influence on the organisation of sanitary aviation in Poland was wielded by the Aviation Foundation, which was created on a social initiative on 25th November 1926. The Committee of Aviation Foundation was also created and bore the name of the First Field Bishop, His Excellency X Bishop Stanisław Gall. The task of the Foundation was to obtain funds through numerous activities such as collections or to search sponsors for the purchase of sanitary planes. The collected money bought two sanitary airplanes and the grant by the name of His Excellency Bishop Gall was created for the students, future sanitary pilots of the Dęblin School of Eagles. The Foundation organised an information-promotional campaign about sanitary aviation where 20000 propaganda leaflets were circulated sucessfully. A special academic work was printed with the title Sanitary Aviation in 300 copies with a preface by X. Cardinal Al. Kakowski (Jachimowski 1937).

Breguet XIV which had already appeared in Poland in 1925 in April was not a lucky plane. Similarly to Hanriot planes, it was assembled in the Warsaw Central Aviation Plant and tested by Lieutenant Kalina. The transfer of the machine to the 1st Aviation Regiment was stalled by the May Coup d'etat and it was only made on 30th October 1926. Breguet XIV was financed due to the genrosity of doctors and pharmacists. The solemn transfer of the airplane took place on the Mokotów airfield in the presence of the Minister of the Interior Gen Sławoj Składkowski into the hands of the Minister of the Military Gen Korzeniowski. The delayed reception of the machine was just the beginning of the misfortunes connected with it. Half 
a year after the plane joined the service on 19.06.1927 Breguet XIV, had a serious accident. The crew composed of the Commander Sergeant pilot Franciszek Przybylski with paramedic senior Sergeant Stanisław Ścibło were transporting a heavily burnt friend Sergeant pilot Piotr Korecki from I Aviation Regiment. As a result of engine failure, they were forced to land in a randomly chosen area near the city. The airplane was severly damaged and had to be transported by rail to the Central Aviation Plant. During the repair, the mechanics were confronted with technical problems piling up due to lack of spare parts. Finally, they managed to bring the plane back to service at the end of May 1928. This time, Breguet had no luck again because it was damaged once more during a rescue operation near Mława. As a result of so called capotage during landing in a random area, the machine was seriously damaged. It was being repaired at the National Aviation Plant (earlier Central Repair Shop) by the same team of mechanics. Unfortunate events had a significant influence on the future of sanitary aviation. Considering the fact that Hanriot airplanes were produced on licence in the training version in Poland and the two serious Breguet accidents, the decision was made to produce a sanitary version based on Hanriot. The team under the leadership of engineer Ryszard Bartel made a Polish rescue version HD-28S (Image 4).

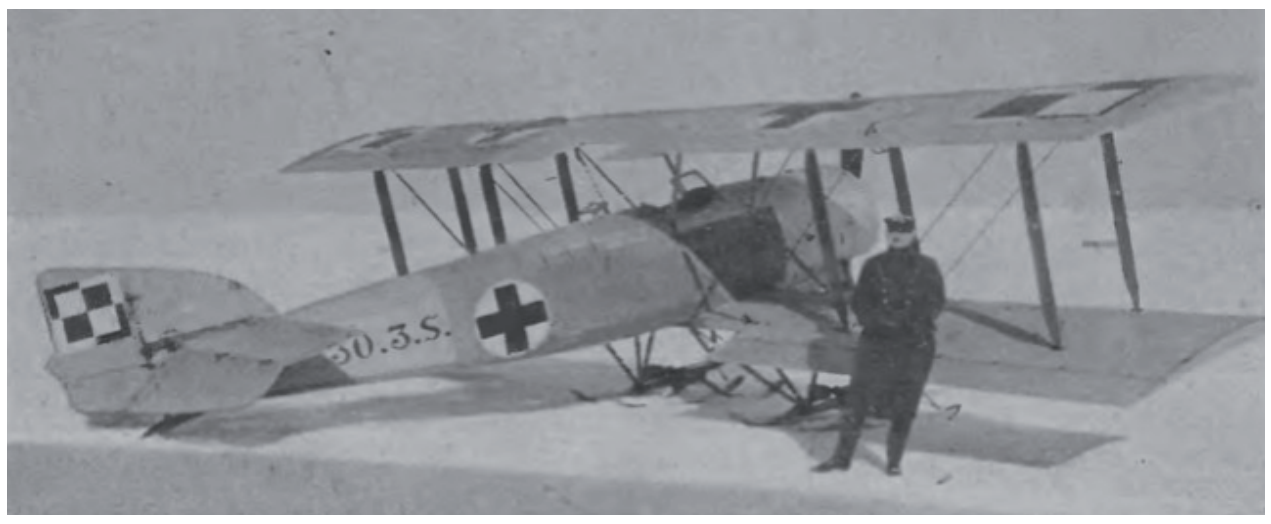

Image 4. Airplane Hanriot (www.samolotypolskie.pl)

Between 1927 and 1928, sixteen planes were produced at the Poznań plant SAMOLOT which were later in aviation regiments. The order for sanitary aircraft was made by the Department of Aviation of the Home Office which was headed by Colonel engineer pilot Ludomił Rayski (Bartnik and Bartnik 2015). 


\section{Development of sanitary aviation in Poland between 1927 and 1939}

The organisation of sanitary aviation in Poland was carried out on many levels. The awareness of the complexity of the problem determined that the authorities created legal regulations defining sanitary aviation as a system. The logistics was undertaken to create a system of sanitary airfields in the whole country. The Home Office in "circular no 34 about transport of civilians by military sanitary airplanes" signed by Minister Sławoj Składkowski defined the guidelines for creation of airfields and special petrol stations, rules for using airplanes and financing sanitary operations. According to the circular, 3 airplanes were ready to use and a subsequent 5-6 machines were expected in a year: "Military Ministry agreed to designate 3 sanitary airplanes for the use of civilians. The agreement enables implementation of this idea in Poland in the nearest future. However, in order to ensure that all the population of Poland can be transported by sanitary airplanes, apart from these 3 airplanes, we will need 5-6 new ones, for the good of the cause, however, there should be no delay but the ready airplanes should be put into action, the more so as the other ones will be ready next year" (Journal of Statutes of Novgorod Voivodship 1927).

3 airplanes were deployed: I Breguet" - near Warsaw city within a 170km radius and 2 and 3 Hanriot" near Lwów and Lida within a $80 \mathrm{~km}$ radius" (Journal of Statutes of Nowogrodzki Voivodship 1927).

In order to increase the range of the planes, special petrol stations were ordered to be built near car petrol stations: "apart from airfields, special stations should be built which can be situated next to car petrol stations. Petrol stations are indispensible because with their proper location, an airplane can cover much greater distance than indicated above" (Journal of Statutes of Nowogrodzki Voivodship 1927).

The dimensions of the airfields were defined - for Hanriot airplanes 400 X400 m: "The two types of airplanes mentioned above can land or take-off from the airfield with an area of 400x400m" (Journal of Statutes of Nowogrodzki Voivodship 1927). 
The direction of the development of sanitary aviation was defined: "It must be emphasised that Hanriot as a lightweight plane cannot take much petrol and beside the pilot, it only carries one person, that is the ill person. This type is not practical and so in the future, the heavier planes will be built for this purpose taking more petrol so that they may fly further. Apart from the ill person, they will also transport a person supervising them: a doctor, paramedic, a member of family)" (Journal of Statutes of Nowogrodzki Voivodship 1927).

In view of a fleet based on airplanes heavier than Hanriot, adequate guidelines were created about the organisation of airfields:...'The best place for an airfield is pastures or dry meadows which can be found near each small town or settlement. Sports fields may be used for that purpose and the other way round, airfields can be used as sports fields. All gymnastics and sports installations should be movable so that they can be removed in the event of an airplane landing. The airfield must have a levelled surface without ditches or ponds. There must be no high buildings, chimneys or trees nearby. If there are elevations, the surface area should be 600x 600 m" (Journal of Statutes of Nowogrodzki Voivodship 1927).

It must be noted that the Home Office provided guidelines about the methods of use and the means of financing sanitary aviation operations. In compliance with them, the call for a medical airplane could only be made by a doctor who turns to the official doctor, or in his absence, directly to local military or civilian authorities, while the payment for the flight, equal to the regular train II class ticket, is covered by the family or the injured himself. "The plane can be only called by a doctor who will find indispensability for the immediate transport of the ill person in order to perform a surgical operation. He makes the call effective through the official doctor. And, in his absence, through local military or civilian authorities (P.K.U, Starost Office, police station etc.). He makes a phone call asking the military authority having at its disposal a sanitary airplane, to send this airplane to the nearest airfield. Having received consent and ensuring the time of the plane's arrival, the ill person must be transported to the determined place and time. To facilitate landing, a fire should be made in the middle of the airfield to indicate the direction of the wind. The amount paid for the transport by plane equals the regular II class train ticket for the length covered by the plane. The transport amounts should be paid in the Treasury Office to renew credit 1/10 of military budget" (Journal of Statutes of Nowogrodzki Voivodship 1927). 
The family was responsible for the transport of the sick person to and from the airfield. The local authorities were given alternative possibilities to make contracts with ambulances of Emergency Services or military sanitary cars. The matter of transport of the sick person to the landing place of the plane or from that place to hospital is left to the initiative of the sick person's family or the regulation of the concerned local authorities. It would be desirable to make a contract about the transport of such ill persons by Emergency Ambulances or military sanitary cars. The military authority, after having received the call, phones the hospital where the ill person will be brought for surgery, sends an airplane and also calls the Emergency or another agreed institution to transport the sick immediately from the airfield to hospital (Journal of Statutes of Nowogrodzki Voivodship 1927).

It was very important at that time to indicate the medical cases eligible for transport by air excluding the conditions of death throes, lung haemorrhage, cases with no prognosis of improvement after surgery and contagious diseases because of technical problems with disinfection of airplanes. "The following cases are eligible for air transport: all fractures, especially skull, which, when not operated on quickly, may be fatal; penetrating wounds of the abdominal cavity; acute attacks of apendicitis; intestinal torsion and incarcerated hernia; haemorrhage and inflammation of abdominal cavity requiring immediate surgery; complicated labour requiring cesarian sections or another surgical procedure; urinary tract diseases requiring immediate surgical procedure. Fatally ill persons in death throes, with lung haemorrhage and cases with no prognosis of improvement after surgery must not be transported. The Military Ministry, in the face of difficulties connected with disinfection, categorically prohibits transport of the contagiously ill" (Journal of Statutes of Nowogrodzki Voivodship 1927).

The circular was accompanied by "Extracts from the Home Office instruction about sanitary aviation" detailing the provisions including rescue equipment of the Hanriot. Reading the original documents regulating the beginnings of sanitary aviation, you may have the impression that they were very general or even inept. Nothing more erroneous. Considering the pioneering character of sanitary aviation in pre-war Poland we should notice how mature the regulations and provisions of the contemporary authorities were. The equipment and infrastructure were very clearly adjusted to the needs. It would be a mistake to compare them with today's 
norms but it would be worthwhile to focus research on their development over the last 100 years, but I leave that to other possible dissertations.

The activity of sanitary aviation in pre-war Poland with the favourable attitude of the government was developing very dynamically for that time. Simultaneously with the success of Polish pilots and constructors on the international arena, the need for more modern flying machines was growing New designs appeared on the drawing boards of constructors throughout Poland.

Modern technical solutions were forced to face up to new challenges and trends. Between 1930 and 1931, Stanisław Działdowski developed an innovative design of a sanitary plane DKD-X Aeromobil (image 5) which could be used as a car, as in James Bond movies, after detaching the wings and the back of the fuselage. Unfortunately, financial problems and the constructor' $\mathrm{s}$ illness prevented completion of the project. The fuselage of DKD-X/2 (Image 5) (an improved version of DKD-X from 1934) was shown in May and June 1938 at the First National Aviation Exhibition in Lwów (Glass 1976).

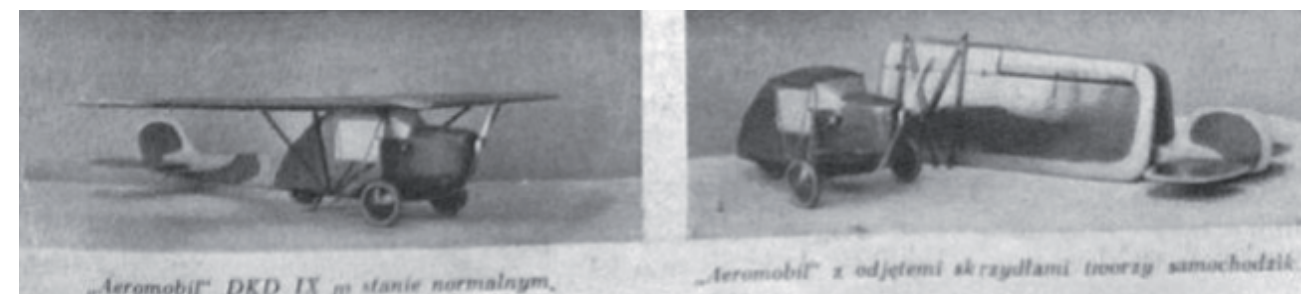

Image 5. Design of DKD-X airplanes (www.samolotypolskie.pl)

In 1931, engineer Jerzy Rudlicki designed a passenger plane Lublin R-XVI based on the R-XI prototype designed in 1929. Both aircrafts were built in the Mechanical Plant Plage and were to replace Junkers F-13 used by PLL LOT. A prototype of RXI (with registration SP-AAC modelled on Foker F-VIIB) was tested on 8.02.1930 and, in June the same year, it was handed over to PLL LOT. After a few trials, the plane was damaged in the air. It was repaired, but in July 1931it crashed again. After the analysis and conclusions (among other things, the plane was too heavy and had lower performance than assumed in the design), Rudlicki redesigned RXI into an improved version R-XVI. The improved version was tested in February 1932. Exploitation trials showed insufficient durability of the construction and, 
consequently, the Lublin R XVI plane lost the competition for substituting the Junkers F 13. The Ministry of Transport competition was won by PWS-24 and Lublin returned to the production plant in order to strenghen the construction. After the changes the plane was assigned RXVIa but was not approved by PLL LOT (Glass 1976). Rudlicki worked out another version based on this project, Lublin R-XVIb, designed for sanitary aviation (drawing 6) The plane, which was tested in May 1933, was handed over to the army. Between 1.06- 4.061933 the VII International Congress of Aviation Medicine was held in Madrid and the plane was entered into the Competition for Sanitary Aviation. Poland won first place and received the Maurice Raphael Cup. Competing for the trophy, Poland defeated the American Ford Trimor, the British Avro 564 and the French Potez 29. The Lublin plant won worldwide fame which was followed by an order from the army for five Lublin R-XVIb machines (Image 6) in June 1934.

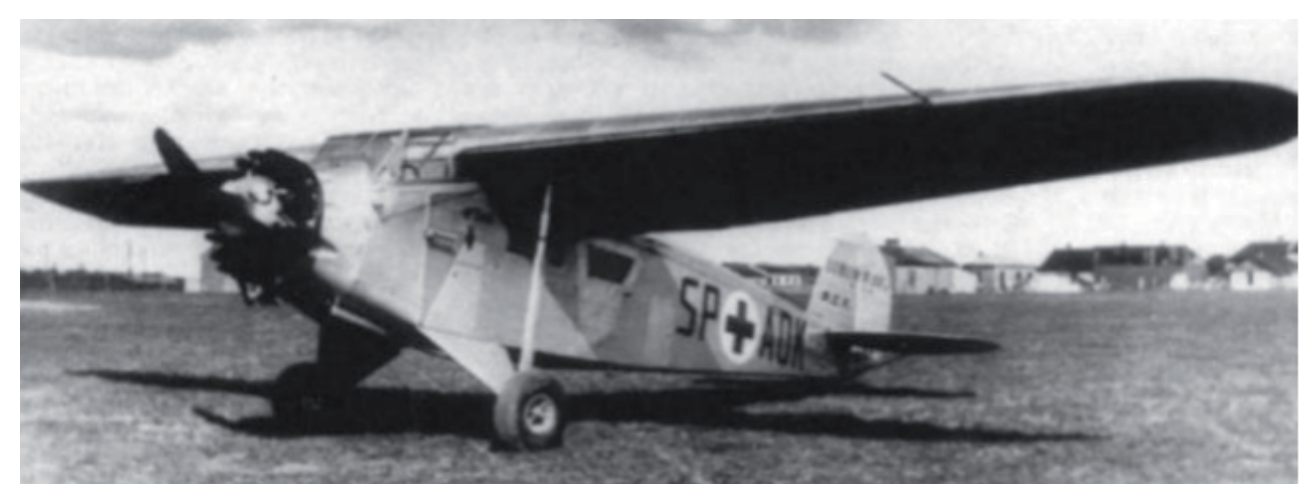

Image 6. Lublin R-XVIb plane (www.samolotypolskie.pl)

The planes were delivered in the first quarter of 1935 and they first reached the army on 9.01.1935. In 1936, they were repaired and served unceasingly until the outbreak of World War II. It is worth mentioning that the R-XVIb piloted by Cpt L. Karczewski demonstrated its potential at the International Competition in Sanitary Aviation in Esch in Luxemburg, where the airdrop of a parachute sanitary patrol was made, composed of J. Węgorzewska, J. Markiewiczówna and L. Dobrowolski. During the September campaign [World War II tr.], at least two Lublin R-XVIb were used for transport of injured soldiers. It is known that one lightly damaged SP-BNO found itself in the hands of the German army and the other in the Soviet hands (Morgała 2003). 
In 1934, due to an order made by the Anti-raid Anti-gas Defence League (the paramilitary organisation which promoted aviation among Polish people), a design of airplane RWD-13 was completed on the drawing board of engineers Stanisław Rogalski, Jerzy Drzewiecki and Leszek Dulęba at the Experimental Aviation Plant.

The prototype was tested on 15th January 1935 (Glass 1976) or (according to other sources) the 14th. The first series of five machines was produced in August and September the same year. The airplane was modified many times during production. According to A. Glass, in the first quarter 1937 (Glass 1976), engineer Bronisław Żurakowski designed a sanitary version of RWD-13 (Morgała 2003 points to the turn of 1936-1937). The modification included, among other things, installation of large doors on the right side of the fuselage, enabling the stretchers to be put with the patient, a change of seating arrangements and fitting in supports to fix the stretchers.

The cost of the prototype design and its production was covered by the Polish Red Cross. A test of the machine was made on 30.04.1937. The same year, eight machines were produced as a series and five others in 1938. It is worth mentioning that in 1937, a sanitary-tourist version RWD-13/T version was also developed with movable fittings. Fifteen machines of that type were built in two versions, tourist and sanitary. A. Morgała states that at the next International Competition of Sanitary Aviation, which took place as part of the conference of the Committee of Military Medicine between 1 and 4.07. 1938 in Esch in Luxemburg, RWD-13S won the 2nd award; the 1st, the Cup of Raphael, was won by LWS-2 t (Morgała 2003).

According to L. Dulęba and A. Glass, RWD 13S won the award in the category of the best sanitary and tourist plane (Dulęba and Glass1983), while Glass, in his book Polish aviation construction up to 1939 points out the reward of Esch city for the best sanitary plane (Glass 1976). The well-constructed RWD 13 was recognised not only in the country but also abroad, and sanitary versions were successfully used in military and civil sanitary aviation (Drawing 7). The developed version of RWD-13 was to be a design developed under engineer S. Rogalski by a team of engineers from the Experimental Aviation Plant between 1935-1936. The prototype of the five seat RWD-15 was tested in spring 1937. The first RWD-15S, the sanitary version was built in December 1938 and was to be the 
successor of RWD-XVIb and was also competing with LWS-2. The Chief of the Department of Sanitary Ministry of Military Affairs in Warsaw, General Stanisław Rouppert, made the decision to order 5 machines RWD-15S, but this has never come to conclusion.

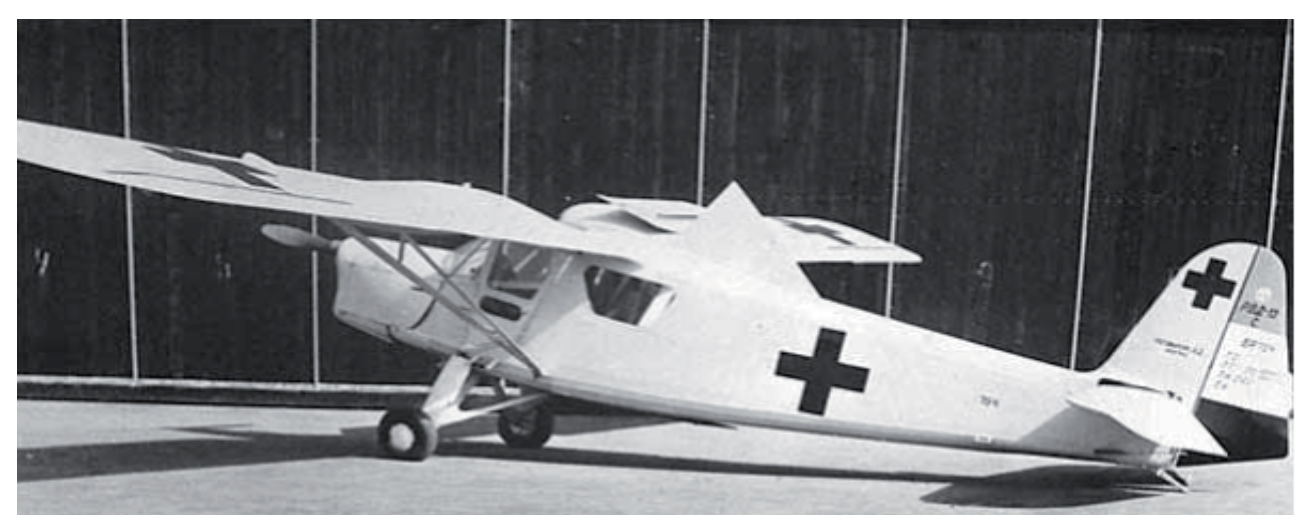

Image 7. Airplane RWD 13S (www.samolotypolskie.pl)

As a result of the bankruptcy of the Mechanical Plant, E. Plage and T. Laśkiewicz, the Lublin Airplanes Production Plant was founded on its basis (Glass 1976). The same year, the new founded state company received an order made by the central management of the Polish Red Cross to develop a new sanitary plane which was to be a successor of R-XVIb. The preliminry project LWS-2 was developed at the beginning of 1936 by engineer Zbysław Ciołkosz, while the engineers Jerzy Teisseyre and Janusz Lange developed a construction project. The prototype was tested in autumn 1937 and spring 1938. After the trials, it turned out that it was only slightly ahead of RXVIb and RWD-13S, which it was to replace. The Polish Red Cross handed over the prototype to the army on 29.05.1938. Between 1 and 4.07.1938 LWS represented Poland together with two other planes, Lublin R-XVIb and RWD -13S, at the already mentioned International Competition of Sanitary Aviation. It received the first prize - the Raphael Cup. The prototype, which was in Krosno in CWL-2 in September 1939, was intercepted by the Germans and its later fortunes are not known. 


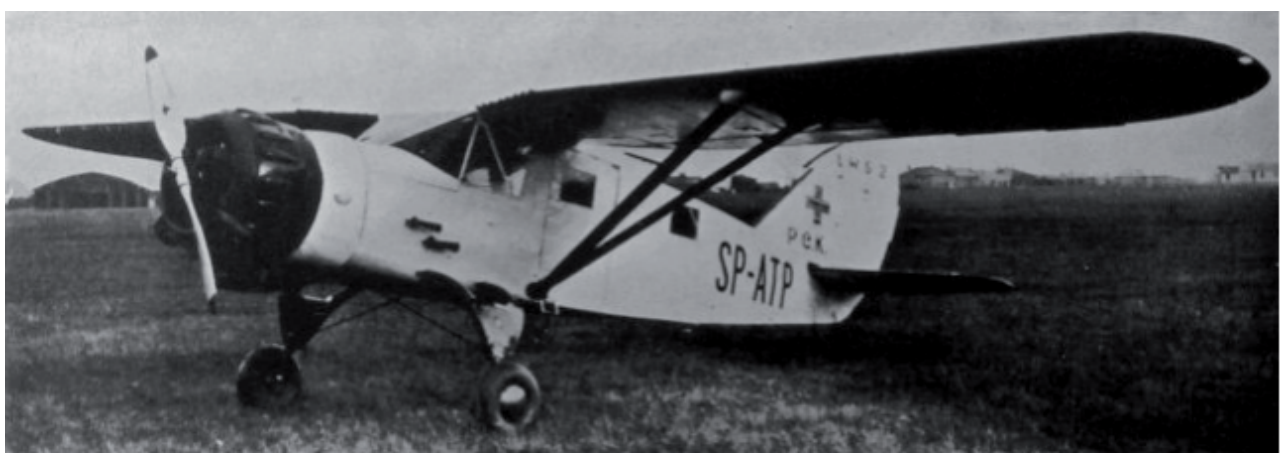

Image 8. Airplane LWS-2 (www.samolotypolskie.pl)

Apart from those successes, one more achievement should be mentioned. There was a special show of rescue from the air as part of the International Competition of Sanitary Aviation in Esch. The demonstration was made on the Lublin R-XVIb airplane piloted by captain L. Karczewski. From the viewers eyes from a height of 300 metres, an air landing was made of a sanitary patrol after the previous landing of medical equipment. The medical team "cheered by the crowd, was composed of two women, Jadwiga Węgorzewska and Irena Markiewiczówna, and L. Dobrowolski.

In September 1939, Poland was in possession of 27 sanitary planes 21 RWD-13, 5R-XVIb and $1|\mathrm{~L}| \mathrm{WS}-2$. After World War II broke out, only some of them were taken over by the Germans and Russians. The remaining machines were evacuated to Romania and Hungary and were detained and consequently taken over by the aviation forces of the respective countries. In this way, the idea of General Sławoj Składkowski came to nothing and sanitary aviation had to wait for better times.

\section{Conclusions}

The French doctor, Eugene Chassaigne`s experience, during World War I and after its end, had enormous influence on the development of sanitary aviation globally. Following the French model, many countries such as the US, Great Britain, Germany, Italy and Poland decided to create their own aviation rescue systems. When in 1924, General Felicjan Sławoj Składkowski initiated the rise of 
Polish sanitary aviation, there were not enough financial resources in the Ministry of Healthcare. Due to the persistence, hard work and determination of aviation enthusiasts and generous donations from the collections, the idea was slowly developing. At first, foreign constructions were used in creation of air rescue, German Albatros C-X was adapted for rescue flights by Polish mechanics. French 2 Hanriot HD 14S and Breguet XIV Tbis were purchased due to the contributions collected by the military sanitary service and the Polish Pharmaceutical Society. At that time all knowledge about aviation was drawn from the experience of our western neighbours. With time, Polish technical ideas appeared and already in 1927 our engineers had developed sanitary versions of Hanriot planes assembled on licence in Poland. Until 1924, most activities were not reflected in regulations. So the period between 1924 and 1927 must be considered the beginning, when the system of air rescue did not yet exist.

In 1927, a circular was made into law, which was the first normative act regulating legal operation of sanitary aviation in the whole country. The logistics were undertaken to create a system of sanitary airfields in the whole country. Since the beginning of the 1930s, Polish constructors have developed their own air designs such as DKD-X Aeromobil, Lublin R-XVIb, RWD-13s or LWS-2, which were many times rewarded at international conferences and had a significant influence on the development of worldwide sanitary aviation. Up to 1939, Poland had 27 sanitary airplanes and a system which supported them. World War II irreparably destroyed many aircraft plants and during the war, many engineers, constructors, pilots and medical staff were killed.

\section{References}

Bartnik, R. and Bartnik, M., 2015. Lotnictwo sanitarne in Polsce. Akademia Obrony Narodowej, Warsaw.

Dulęba, L. and Glass, A., 1983. Samoloty RWD. Wydawnictwo Komunikacji i Łączności, Warsaw.

Journal of Statutes of Nowogrodzki Voivodship, 1927. Redakcja $i$ Administracja Nowogródek, Urząd Wojewódzki, Rok VII, Nowogródek- March 1927, No 3.

Gałązkowski, R. and Kłosiński, P. 2005. Polskie Lotnictwo Sanitarne 1955-2005. Wydawnictwo Borgis, Warszawa. 
Glass, A., 1976. Polskie Konstrukcje Lotnicze 1893-1939. Wydawnictwo Komunikacji i Łączności, Warsaw.

Armstrong, H.G.,1952. Principles and Practice of Aviation Medicine, Williams E Wilkins, California, 215.

Jachimowski, T., 1937. Pierwszy Biskup Wojsk Polskich. Warsaw.

Haller Jr, J. S., 2011. Battlefield Medicine. A history of the Military Ambulance from the Napoleon Wars through World War I. Southern Illinois University.

Sarnecky, M.T., 1999. A History of the US Army Nurse Corps. Henry M. Jackson Foundation, 250.

Morgała, A., 2003. Samoloty Wojskowe w Polsce 1924-1939. Wyd. Bellona, Warsaw.

Przybylski, M., 2003. Zespót Lotnictwa sanitarnego we Wroctawiu, 1955-1975 [in] Janiszewski S. (ed.), Lotnictwo- stulecie przemiany. Oficyna Wydawnicza Politechniki Wrocławskiej, Wrocław.

www.flickr.com [Accessed 13 Mar 2018].

www.fr.wikipedia.org/wiki/Dorand_AR.I [Accessed 13 Mar 2018].

www.samolotypolskie.pl [Accessed 13 Mar 2018]. 